\title{
When is a partner/LLP member not a partner/LLP member? The interface with employment and worker status
}

\author{
Elspeth Berry*
}

\begin{abstract}
The answer to the question of whether a partner can also simultaneously be an employee of his partnership has long been considered to be settled law. However, the introduction of limited liability partnerships (LLPs) in 2001 has not only raised the new question of whether LLP members can also be employees but has, in doing so, reopened the question of the employment status of partners, questions which now need to be viewed in the context of the widespread practice of having both equity and other types of partner/member. Furthermore, with much legislation now giving rights to 'workers' rather than employees, the question has arisen of whether LLP members or partners can also simultaneously be workers, regardless of whether they can also be employees. The answers to these questions go to the very heart of what the law regards as an employeremployee or firm-worker relationship, yet recent legislation and jurisprudence have failed to clarify the legal position. This article explores the employee and worker status of partners and LLP members, and the consequences both for them and for the development of the law.
\end{abstract}

\section{$1 \quad$ Introduction}

In order to establish whether partners or LLP members can (and should be allowed to) be simultaneously also employees or workers, and whether there is any difference for this purpose between different types of partner/member, this article first assesses the current state of the law, and then examines the case for treating partners and LLP members similarly despite the differences between partnerships and LLPs. It then compares the consequences of the different legal statuses for the individuals, their firms and third parties. The challenges encountered in applying the law in practice to differentiate between partners/members, employees and workers are then analysed. Finally, conclusions are drawn about the current state of the law and likely future developments.

\section{Partner and/or emplovee? : the rule in partnership law against dual status}

It has long been established by the courts that a true partner (typically an equity partner who takes part in management, contributes capital and shares profits) cannot also be an employee of the partnership, because a partnership is not a separate legal person to its partners (except in Scotland ${ }^{1}$ ) and it is not possible in principle for an individual to employ himself: Mathew LJ in Ellis $v$ Joseph Ellis \& Co described the circumstance of being both an employer and an employee as 'a legal impossibility'. ${ }^{2}$ This approach is consistent with the unitary conception of the employer. ${ }^{3}$ In addition, as Lord Donaldson MR noted in Cowell $v$ Quilter Goodison Co Ltd, the partnership relationship is 'wholly different' from the employment relationship, ${ }^{4}$ and this is discussed further below. As recently as 2009, the Employment Appeal Tribunal (EAT) in Train v DTE Business Advisory Services Ltd \& Associated Companies t/a DTE Chartered Accounts and others

\footnotetext{
* Reader in Law, Nottingham Law School, Nottingham Trent University, email elspeth.berry@ntu.ac.uk, ORCID ID orcid.org/0000-0001-8325-5356. I wish to thank Professor Geoffrey Morse, Kay Wheat, Peter McTigue and the anonymous reviewers for their helpful comments. Any errors or omissions remain my own.

1 Partnership Act, s 4(2).

2 [1905] 1 KB 324 (CA) 329.

3 Jeremias Prassl, The Concept of the Employer (OUP, 2015) 16-19.

4 [1989] IRLR 392 (CA) 393.
} 
described the premise that 'a full equity partner cannot be an employee of a business' as 'uncontroversial'. ${ }^{5}$

This established view was challenged in Clyde \& Co LLP v Bates van Winkelhof by the charity Public Concern at Work, which argued that it was not the law that partners could not also be employees, since the judgment in Ellis predated s82 of the Law of Property Act 1925, which provides that 'Any covenant....or agreement entered into by a person with himself and one or more other persons shall be construed and be capable of being enforced.... as if.... entered into with the other person or persons alone'. Since a partner could make some contracts with the partners collectively, there was no reason why he could not be employed by the partnership. Lady Hale, giving the leading judgment, described this as 'a serious challenge', ${ }^{7}$ while Lord Clarke, despite dissenting on other points, stated 'There is to my mind much to be said for the view that if the appellant had been a partner...she would now be treated as an employee. ${ }^{8}$

However, both explicitly left this issue undecided, while Lord Carnwath, citing in support the Law Commissions ${ }^{9}$ and Lindley \& Banks on Partnership, ${ }^{10}$ said that he was 'unpersuaded': ${ }^{11}$ first, the judgment in Cowell did not predate s82; second, Ellis did not turn simply on the lack of capacity to contract but on the nature of the relationship of the parties, which was one of partnership; and third, a contract between a partner and his co-partners, which might be effective in law for many purposes, could not be equated with a contract between the partner and the firm as such, since each partner was an essential part of the firm. These cogent points found favour in the subsequent cases of Walsh and others $v$ Needleman Treon (A Firm) and others and Altus Group (UK) Limited v Baker Tilly Tax and Advisory Services LLP and another, in which the courts held that the traditionally understood position of partners was 'common ground'12 and 'settled ${ }{ }_{a w}{ }^{\prime},{ }^{13}$ and that there was 'much to be said for Lord Carnwath's... explanation'. ${ }^{14}$

\section{LLP member and/or employee?: s4(4) of the LLP Act}

The root of the problem of the employment status of LLP members is s4(4) of the Limited Liability Partnerships Act 2000 (LLP Act), which purports to determine whether an LLP member can also be an employee. It provides that:

'A member of a limited liability partnership shall not be regarded for any purpose as employed by the limited liability partnership unless, if he and the other members were partners in a partnership, he would be regarded for that purpose as employed by the partnership.'

At first blush, therefore, the position seems straightforward: s4(4) cross refers to partnership law, which prohibits simultaneous partner and employee status. This is supported by the rationale for $s 4(4)$ provided during the passage of the Bill 'to ensure that members are not employees of the [LLP]'15 - and the explanation that s6 (on the agency of members) 'should not mean that members are treated as employees....It is our intention to make sure that members should not be

\footnotetext{
5 [2009] UKEAT 0201/08/0601 [2009] All ER (D) 134 (Mar) [19] (Judge Peter Clark).

${ }^{6}$ [2014] UKSC 32, [2014] 1 WLR 2047.

7 (n6) [29].

8 (n6) [52].

${ }^{9}$ Law Commission and Scottish Law Commission, Report on Partnership Law (Law Com No 283/Scot Law Com No 192, 2003).

${ }^{10}$ Roderick I'Anson Banks, Lindley \& Banks on Partnership (19 ${ }^{\text {th }}$ edn, Sweet and Maxwell, 2010) para 5-55.

11 (n6) [59].

12 Walsh [2014] EWHC 2554 (Ch) [20] (Barling J).

${ }^{13}$ Altus [2015] EWHC 12 (Ch), [2015] STC 788 [163] (Judge Keyser QC).

${ }^{14}$ Altus (n13) [163] (Judge Keyser QC).

${ }^{15}$ Lord McIntosh of Haringey (HL Deb 24 January 2000, vol 608, cols 1359-1360) citing Baroness Buscombe (HL Deb 9 December 1999, vol 607, col 1424).
} 
regarded as employees because they are members'. ${ }^{16}$ Accordingly, the courts in Tiffin $v$ Lester Aldridge LLP ${ }^{17}$ and Reinhard $v$ Ondra LLP and others ${ }^{18}$ concluded that since the LLP member in question would have been held to be a partner had the LLP been a partnership, and therefore could not have been employed by it, he could not be an employee of the LLP.

However, as the Court of Appeal noted in Tiffin, if s4(4) were to be applied literally, no LLP member could ever be an employee, since he could never have been an employee when a partner. This would make the second part of s4(4) redundant although, as it further noted, '[u]nfortunately, the authors of section 4(4) were apparently unaware of this'. In fairness, during its legislative passage Lord Phillips of Sudbury presciently described it as 'work for lawyers, however well intentioned' while Baroness Buscombe noted 'I have read it more than half a dozen times and wonder if we can improve on the wording'. ${ }^{19}$ The unsatisfactory wording may be due to a change of approach during the legislative process, from simple confirmation that membership status would not of itself confer employment status, to a complete prohibition on members being an employees: it was at one point proposed 'that the Bill should make clear that a member of an LLP will not be an employee of the LLP unless there is express agreement to that effect between the member and the LLP' (author's emphasis), ${ }^{20}$ but it was subsequently noted that this was inconsistent with employment law which, as discussed below, does not regard as conclusive the labels given by the parties to their relationship ${ }^{21}$ and explained that 'Members of an LLP are not usually treated as employees' and 'will not be treated as employees (in the context of employment rights)' (author's emphasis). ${ }^{22}$ Nonetheless, as Warren J put it in Ondra: ${ }^{23}$ 'Section 4(4), on a literal wording, leads to an absurdity in that it posits an impossible situation under English law'. The question which arises, then, is what the second part of s4(4) means, if anything. In attempting to address this question, the courts have created some confusion.

First, in so far as s4(4) replicates partnership law, the doubts cast by Lady Hale and Lord Clarke in some of the judgments in Clyde ${ }^{24}$ on whether partnership law does indeed prevent a partner from being an employee equally cast doubt on whether s4(4) prevents an LLP member from being an employee.

Second, the Court of Appeal in Tiffin laid down an unnecessarily complicated twopart test. ${ }^{25}$ First, it was necessary to ascertain whether the member would have been regarded as a partner had the firm been a partnership. If he would, then he could not be an employee. If he would not, a second enquiry was required as to whether he would have been an employee of the notional partnership. In Clyde the Supreme Court held that this two-stage process was unnecessary, Lady Hale stating that

'there is no need to give such a strained construction to section 4(4). All that $[s 4(4)]$ is saying is that, whatever the position would be were the LLP

\footnotetext{
${ }^{16}$ Lord McIntosh of Haringey at the Second Reading of the Limited Liability Partnerships Bill in the House of Lords (HL Deb 9 December 1999, vol 607, col 1443).

17 [2012] EWCA Civ 35, [2012] ICR 647.

18 [2015] EWHC 26 (Ch), [2015] All ER (D) 69 (Jan) (main judgment).

19 HL Deb 24 January 2000, vol 608, col 1360. Ironically, Nick Gibb MP explained that 'Clause 4(4) has been changed to make absolutely [sic] that a member of [an LLP] is not an employee' (PBC Deb (F) 13 June 2000).

20 Baroness Buscombe, HL Deb 9 December 1999, vol 607, col 1429.

${ }^{21}$ Lord McIntosh of Haringey (HL Deb 24 January 2000, vol 608, col 1361).

22 House of Commons Research Paper 00/54 22 May 2000: Limited Liability Partnerships Bill [HL] Bill 108 1999-2000, 12 and 24.

${ }^{23}$ (main judgment) (n18) [32] (Warren J).

$24(\mathrm{n} 6)$.

25 (n17) [32] (Rimer L).
} 
members to be partners in a traditional partnership, then the position is the same in an LLP'. ${ }^{26}$

Admittedly, Tiffin concerned employment status whereas Clyde involved worker status, and the Supreme Court's comments on the interpretation of s4(4) and employee status might therefore be obiter dicta, because they were '[a]n opinion given in court [which is] not necessary to the judgment ${ }^{27}$ rather than forming part of the binding ratio decidendi. However, it was subsequently held in Ondra 28 that it had indeed been necessary for the Supreme Court to interpret s4(4) in order to determine whether it applied to workers, and that its comments on s4(4) were therefore not obiter.

Finally, the Court of Appeal in Tiffin provided apparently contradictory statements on whether a member could also be an employee. On the one hand, the two part test appears to rule out such dual status, and indeed the Court of Appeal explicitly disagreed with the EAT's suggestion in Kovats $v$ TFO Management LLP and another ${ }^{29}$ that even where a member would have been a partner, there was still scope to examine whether he would also have been an employee. ${ }^{30}$ On the other, the Court of Appeal stated that

'it is clear that a member of a limited liability partnership can be an employee of it: that is what section 4(4) recognises'. ${ }^{31}$

This apparent conflict can be resolved once it is recognised that the only members who 'can' be employees are those who are registered as members but are not true members. The court in Ondra subsequently drew this distinction more clearly, giving as an example of the latter

'an employee [who] is made a member of the LLP but obtains no rights other than the right to continue to receive his salary',

and noting that such a person would be in a similar position to 'a so-called salaried partner in a traditional partnership in those cases where the salaried partner is not a partner at all'. ${ }^{32}$

Partnership law has never imposed a blanket ban on all partners from simultaneously being employees, ${ }^{33}$ only on true partners (typically those who take part in management, contribute capital, and/or shares profits). Thus, while a true LLP member cannot be an employee, a person who is described as a member but who is not a true member can be.

The law has recognised the possibility of different categories of LLP membership in other contexts. When LLPs were first introduced, HMRC taxed all registered LLP members in the same way as true partners, ${ }^{34}$ an approach which was consistent with the failure of the legislature to recognise the distinction between true and other partners when drafting s4(4). The government considered that HMRC's failure to make the necessary equivalent distinction between true and other LLP members gave rise to unfairness, market distortions and tax avoidance ${ }^{35}$ and

\footnotetext{
${ }^{26}$ (n6) [21].

27 Bole v Horton (1672) Vaugh 360, 382; 124 ER 1113, 1124; see further Rupert Cross and JW Harris, Precedent in English Law (4 ${ }^{\text {th }}$ edn, OUP 1991) 41-57.

28 [2015] EWHC 1869 (Ch), [2015] All ER (D) 314 (Jun) (supplementary judgment).

29 [2009] UKEAT 0357/08/2104, [2009] ICR 1140.

${ }^{30}$ Although the EAT in Kovats stated that the question of whether a person could be both an LLP member and an employee was not relevant on the facts, it clearly considered it to be possible since it expressly approved the Employment Tribunal's examination of Kovats' employment status when the Tribunal had already held that he was a partner.

${ }^{31}$ Tiffin (CA) (n17) [34] (Rimer LJ).

32 (main judgment) (n18) [50] (Warren J).

${ }^{33} \mathrm{Cf}$ the suggestion in Jeremias Prassl 'Members, partners, employees, workers? Partnership law and employment status revisited' (2014) 43(4) ILJ 495, 501-502.

${ }^{34}$ Income and Corporation Taxes Act 1988, s 118ZA, now ITTOIA 2005, s 863.

35 HMRC Partnerships: A review of two aspects of the tax rules - Consultation document 20 May 2013 [2.8]-[2.10].
} 
therefore introduced remedial provisions ${ }^{36}$ in order to distinguish between LLP members who are in fact disguised employees and should be taxed as such, and true members who continue to be taxed in the same way as true partners. ${ }^{37}$ Arguably, different categories of LLP membership were also acknowledged in $F$ \& $C$ Alternative Investment (Holdings) Ltd $v$ Barthelemy and others, in which the court held that an LLP member who did not have control over the affairs or property of the LLP did not owe it a fiduciary duty. ${ }^{38}$

An interpretation of s4(4) of the LLP Act that aligns partners and LLP members in relation to employment status is consistent with the similarities of their roles. Partnerships and LLPs both require two or more persons to carry on business together with a view of profit, ${ }^{39}$ albeit that this requirement only applies to LLPs on formation; and as the roles of both partners and members combine ownership with management, many of the legislative provisions which govern these roles in default of contrary agreement - including their rights, duties, admission and withdrawal - are similar. ${ }^{40}$ Aligning their treatment is also consistent with the tax position, because LLP members are treated as partners for tax purposes ${ }^{41}$ and partners and members can only be taxed as employees or as self employed and not both.

There are, of course, important differences between partnerships and LLPs, reflecting the fact that LLPs were introduced after intensive lobbying from large professional practices who were unhappy with the unlimited personal liability of partners in general partnerships ${ }^{42}$ in the context of ever increasing partnership sizes, and of an increase in the number and extent of claims against professional firms who were perceived to have deep pockets because of that unlimited liability. ${ }^{43}$ What they sought, and largely achieved, was a corporate body with separate legal personality ${ }^{44}$ whose members have limited liability, ${ }^{45}$ albeit with exceptions. ${ }^{46}$ The quid pro quo for these advantages is that while partnerships have complete flexibility and informality, with no statutory intrusion into their governance and complete privacy of internal arrangements, LLPs have registration, ${ }^{47}$ accounting and filing requirements ${ }^{48}$ similar to companies, although they are not obliged to register any formal internal agreement.

\footnotetext{
${ }^{36}$ Income (Trading and Other Income) Act 2005, ss 863A-G. Broadly, a member will be treated as a disguised employee if at least $80 \%$ of his remuneration is disguised salary (ie does not vary with reference to the profits or losses of the LLP), the mutual rights and duties of the LLP and its members give him significant influence over the affairs of the LLP, and his capital contribution is less than $25 \%$ of his disguised salary.

37 Finance Act 2014, Sch 17 Pt 1.

38 [2011] EWHC 1731 (Ch), [2012] Ch 613 [217-221] (Sales J).

39 Partnership Act 1890, s 1(1), and the Limited Liability Partnerships Act 2000 (the LLP Act), s 2(1).

40 Partnership Act, ss 24-30; LLP Act, s 5(1) and s 6(1)-(3) and the Limited Liability Partnerships Regulations 2001 (SI 2001/1090) (the LLP Regulations 2001), Regs 7-8.

${ }^{41}$ Income Tax (Trading and Other Income) Act 2005, s 863. The partnership/LLP itself is tax transparent (unlike a company) and so profits are taxed only once, in the hands of the partners/members.

42 Partnership Act, s 9 and the Civil Liability (Contribution) Act 1978, s 3.

${ }^{43}$ See further Elspeth Deards, 'Partnerships and the Problem of Unlimited Liability' [2000] CLLR 73 and Vanessa Finch and Judith Freedman, 'Limited Liability Partnerships: Have Accountants Sewn up the "Deep Pockets" Debate?' (1997) JBL 387.

44 LLP Act, s 1(2).

${ }^{45}$ LLP Act, s $1(2)$ and (4).

${ }^{46}$ See, for example, the LLP Act, s 6(4) and the Insolvency Act 1986, ss 213-214.

${ }^{47}$ For an LLP to be formed it must not only satisfy the substantive requirements of the LLP Act, s 2(1), but the members must subscribe to an incorporation document, which is registered together with a statement of compliance.

${ }^{48}$ See, for example, the LLP Act, s 3, CA 2006, s 854 as modified by the Limited Liability Partnerships (Application of Companies Act 2006) Regulations 2009 (SI 2006/1804) (the LLP Regulations 2009), Reg 30, and the Limited Liability Partnerships (Accounts and Audit) (Application of Companies Act 2006) Regulations 2008 (SI 2008/1911).
} 
Nonetheless, it is submitted that these differences do not justify different approaches being taken to the employment status of partners and LLP members. First, these differences explain why it was necessary to include s4(4) in the LLP Act, in order to ensure that they did not result in different approaches being taken to employment status. Second, although separate legal personality means that there is no conceptual difficulty in an LLP employing its members just as a company can employ its directors, and the Supreme Court in Clyde suggested that the arguments about whether a partner could be an employee might be different if the firm had separate legal personality, ${ }^{49}$ there are doubts as to whether a Scottish partnership - which does have separate legal personality ${ }^{50}$ can employ a partner. ${ }^{51}$ Furthermore, when the Law Commissions proposed that an English partnership be given separate legal personality, they also proposed that it should not be able to employ its partners because 'the status, rights and obligations of a partner [are] wholly different from those of an employee' and 'a dual role as a partner and an employee could call into question the tax status and even the existence of a partnership'. ${ }^{52}$ Third, although s1(5) of the LLP Act states that

'except as far as otherwise provided by this Act or any other enactment, the law relating to partnerships does not apply to a limited liability partnership',

the LLP legislation actually makes considerable reference to partnership law. It is thus inevitable that the courts will place considerable reliance on existing partnership law when interpreting those elements of the LLP legislation, and indeed s4(4) is not merely in the category of provisions which are modelled on partnership law, it explicitly refers to it.

\section{$4 \quad$ LLP members/partners and worker status}

The Supreme Court in Clyde 53 ruled that the determination of whether an LLP member was a worker under s230(3)(b) of the Employment Rights Act 1996, and thus protected as a whistleblower, did not depend on whether a partner in the same situation would have been a worker, because s4(4) of the LLP Act only applied to employee and not worker status. There was thus no prohibition in principle on a true member being a worker.

Whether the same applies to true partners has not yet been established. Given the alignment of partners and LLP members in terms of employee status, drawing a distinction between them in terms of worker status could cause confusion, and the similarities in their roles suggest that if being a worker can be consistent with being a true LLP member, it can also be consistent with being a true partner. There are also compelling policy reasons, discussed below, in favour of extending worker status. However, as s4(4) does not apply to worker status there is no statutory alignment of LLP members and partners in this respect, while s1(5) explicitly allows a divergence. In addition, a partnership's lack of separate legal personality means that, unlike an LLP, it may not be regarded as 'another party' for the purposes of the statutory definition of a worker. This will be discussed further below.

\section{$5 \quad$ The consequences of status}

\footnotetext{
49 (n6) [18] (Lady Hale).

${ }^{50}$ Partnership Act, s 4(2).

51 In Allison v Allison's Trustees (1901) 12 SLT 33 (IH) 35 the court described the pursuer's employment as 'a complex contract implying partnership as well as service', while in Fife County Council v Minister of National Insurance 1947 SC 629 (IH), 636 (Lord Cooper P) it '[a]ssum[ed] without deciding that in Scotland a partner can enter into a contract for service with his own firm' although Lord Keith stated (at 639) that 'I wish to reserve my opinion as to whether a partnership can so employ one of its partners under Scots law'.

52 Law Commission and Scottish Law Commission, Report on Partnership Law (n9) [13.41]-[13.43]. 53 (n6).
} 
It is vital for individuals, firms and third parties to know whether a person is a partner/LLP member, or an employee and/or a worker, because of the consequences that flow from a particular status.

\section{a) Internal rights and duties}

Although internal duties and financial and management rights are governed by agreement rather than statute, and are therefore not necessarily determined by whether the individual is a partner/member or an employee or worker, the default rules which apply under the Partnership Act/the Limited Liability Partnership Regulations 2001 (LLP Regulations) ${ }^{54}$ in the absence of contrary agreement are applicable only to partners/an LLP and its members, ${ }^{55}$ while there are also rights and duties which attach only to employees, including the duty of obedience, ${ }^{56}$ or to employers, including the duty to pay wages ${ }^{57}$ and certain statutory duties (discussed further below). That said, the rights and duties have some similarities; for example, the duties imposed on partners/LLP members and on employees ${ }^{58}$ include a duty not to compete with the business, ${ }^{59}$ they are all subject to a duty of skill and care ${ }^{60}$ (although the standard may vary ${ }^{61}$ ) and their acts may give rise to vicarious liability on the part of the firm ${ }^{62}$ or employer. ${ }^{63}$

A further difference is that on dissolution of a partnership an employee may have a claim for a breach of his employment contract, albeit only if it is for a fixed term or there is a notice period and dissolution occurs prior to the end of this, ${ }^{64}$ and only if either the dissolution is total (i.e. the business comes to an end), or is what is sometimes described as a partial or technical dissolution (i.e. there is a change of partner but the business continues) but the firm is small or the employment contract was clearly made with reference to the original business or the original personnel only. ${ }^{65}$

\section{b) Non-discrimination and other statutory rights}

Employees benefit from some statutory protection that is not available to partners/LLP members, for example unfair dismissal, redundancy, and maternity and parental leave. ${ }^{66}$ Thus, in Palumbo $v$ Styliano ${ }^{67}$ the tribunal's conclusion that Palumbo had been a partner and not an employee meant that the termination of

\footnotetext{
54 SI 2001/1090.

55 Partnership Act, ss 24, 25, 35, 37, 39, 42 and 44 and LLP Regulations 2001, Regs 7 and 8.

${ }^{56}$ Laws v London Chronicle (Indicator Newspapers) Ltd [1959] 1 WLR 698 (CA).

57 Miles $v$ Wakefield MDC [1987] AC 539.

${ }^{58}$ Const v Harris (1824) Turn \& R 496, (1924) 37 ER 1191 (partners), F \& C (n37) (LLP members) and Boston Deep Sea Fishing and Ice Co $v$ Ansell (1888) 39 Ch D 339 (CA) (employees).

59 Partnership Act, s 24 (partners), LLP Regulations 2001, Reg 7 (LLP members) and Hivac Ltd v Park Royal Scientific Instruments Ltd [1946] Ch 169 (employees).

60 Tann v Herrington [2009] EWHC 445 (Ch), [2009] Bus LR 1051 (partners) and Harmer v Cornelius

(1858) 5 CBNS 236 (QB) (employees). It has not yet been established whether LLP members owe a duty of care to the LLP, although it is likely that they do, based either on their fiduciary duties or on ordinary principles of tort law.

${ }^{61}$ See further Elspeth Berry, 'Partnership options in the UK: good things come in threes' in Robert W. Hillman and Mark J. Loewenstein (eds), Research Handbook on Partnerships, LLCs and Alternative Forms of Business Organizations (Edward Elgar 2015).

62 Partnership Act, ss 5, 6 and 10 and the LLP Act, s 6; see further Dubai Aluminium Co Ltd v Salaam [2002] UKHL 48, [2003] 2 AC 366 [103ff] (Millett L]) and Elspeth Berry, 'The Criminal Liability of Partnerships and Partners: Increasing the Divergence between English and Scottish Partnership Law?' (2014) 7 JBL 585, 591-593, 605.

${ }^{63}$ Majrowski v Guys and St Thomas Trust [2006] UKHL 34, [2007] 1 AC 224 and Lloyd v Grace, Smith \& Co [1912] AC 716 (HL).

${ }^{64}$ Briggs $v$ Oates [1990] ICR 473.

${ }^{65}$ Brace v Calder [1895] 2 QB 252 (CA), Phillips v Alhambra Palace Company [1901] QB 59 (QB), Briggs (n64) 482 (Scott J) and Rose $v$ Dodd [2005] EWCA Civ 957, [2005] ICR 1776 [48-54]

(Mummery L]); see further Mark Freedland, The Personal Employment Contract (2003 OUP) 453-454. ${ }^{66}$ See further the Employment Rights Act 1996 and the Maternity and Parental Leave etc Regulations 1999 (SI 1999/3312).

67 [1966] 1 ITR 407.
} 
his engagement when the business was sold did not entitle him to a redundancy payment or to the period of notice to which employees were statutorily entitled. Similarly, in Tiffin ${ }^{68}$ the Court of Appeal's conclusion that Tiffin was an LLP member rather than an employee meant that he was not entitled to claim compensation for unfair dismissal or redundancy when he was required to retire. This lack of protection is part of a wider pattern of reduced coverage of employment protection that has caused considerable concern. ${ }^{69}$

Of course, where statutory rights attach to worker status, for example the protection of whistleblowers, ${ }^{70}$ limitations on working time ${ }^{71}$ and prohibitions on discrimination in relation to part time work, ${ }^{72}$ true LLP members (and possibly partners) may benefit in the same way as employed members. However, this will only assist if they fall within the definition of 'worker' in the relevant legislation and it is noteworthy that, in the light of Clyde, the government has permitted the exclusion from automatic enrolment in a workplace pension of true LLP members (although not those who are taxed as employees ${ }^{73}$ ). ${ }^{74}$

In any event, the prohibitions on discrimination largely apply also to partners/LLP members $^{75}$ (although they do not benefit from protection against discrimination in relation to fixed term contracts ${ }^{76}$ ). Thus, in Train $^{77}$ the EAT's conclusion that Train was a partner meant that he could not bring a claim for unfair dismissal, although he could still bring a claim for unlawful age discrimination since the relevant equality legislation also applied to partners. Furthermore, true partners/LLP members cannot be expelled unless there is a power to do so in the partnership/LLP agreement ${ }^{78}$ and any procedure specified therein is followed. ${ }^{79}$

\section{c) Restrictive covenants}

In principle, a restrictive covenant entered into with a partner/member or employee will be enforceable if it is reasonable between the parties and in accordance with the public interest in individuals being able to carry on their trade or profession freely, and thus is no greater than is reasonably necessary to protect a legitimate interest of the firm. ${ }^{80}$ However, covenants entered into with partners have not been scrutinised as strictly by the courts as those with employees, ${ }^{81}$ because the parties are in an equal bargaining position and are aware of the nature and extent of the restrictions required to protect the firm's business, ${ }^{82}$ and because the covenant is entered into by each partner and may become binding on any one of them. ${ }^{83}$ Whether a partner or, presumably, an LLP

\footnotetext{
68 [2012] EWCA Civ 35 [2012] ICR 647.

69 Prassl, The Concept of the Employer (n3) Ch 3.

${ }^{70}$ Employment Rights Act 1996, ss 43-43L and 230(3)(b).

71 Working Time Regulations 1998 (SI 1998/1833).

72 Part-term Workers (Prevention of Less Favourable Treatment) Regulations 2001 (SI 2002/1551).

73 (n37).

74 The Occupational and Personal Pension Schemes (Automatic Enrolment) (Miscellaneous

Amendments) Regulations 2016 (SI 2016/311), Reg 4.

${ }^{75}$ For example, in Seldon v Clarkson Wright \& Jakes (a partnership) [2012] UKSC 16, [2012] 2 CMLR

50 a partner who had been compulsorily retired in accordance with the partnership agreement was able to bring a claim for discrimination on grounds of age.

${ }^{76}$ See further the Fixed-term Employees (Prevention of Less Favourable Treatment) Regulations 2001 (SI 2002/2034).

77 (n5).

78 Partnership Act, s 25 and the LLP Regulations 2001, Reg 8.

79 See further Peter De Maria, 'Watertight Agreements' (2014) 152 (1446) Accountancy 72, 74.

${ }^{80}$ Nordenfelt $v$ Maxim Nordenfelt Guns and Ammunition Co. Ltd [1894] AC 535 (HL).

${ }^{81}$ Whitehill $v$ Bradford [1952] Ch 236 (CA) and Prescott $v$ Dunwoody Sports Marketing [2007] EWCA Civ 461, [2007] 1 WLR 2343.

82 Dallas McMillan \& Sinclair v Simpson (1989) SLT 454 (OH) 456 (Lord Mayfield) and Naish v Thorp Wright \& Puxon (a firm) (QB, 21 May 1998).

${ }^{83}$ Bridge $v$ Deacons [1984] AC 705 (PC) 716 (Fraser LJ), citing the Australian case of Geraghty $v$ Minter (1979) 142 CLR 177, 198 (Mason J).
} 
member, is a true partner/member or an employee could therefore determine the enforceability of any covenant entered into by them.

\section{d) Liability of partners/LLP members}

A further reason why true partner status is significant is that $s 9$ of the Partnership Act provides that (true) partners are personally liable to third parties for the partnership's debts and obligations. ${ }^{84}$ Section 14 does extend this liability to those who are not true partners but appear to be partners, but only in limited circumstances; ${ }^{85}$ the person must have represented himself or knowingly allowed himself to be represented as a partner in a particular firm, and the third party must have given credit to the firm in reliance on the representation. For example, in Walsh ${ }^{86}$ the claimants sued a partnership and its partners, and a dispute arose as to whether one of the defendants, Prior, was a partner in the firm or a person who had been held out as such and thus liable to the claimants, or only an employee and therefore not liable. The court held that Prior was an employee rather than a true partner; but had been held out as a partner because he had sought and been granted partner status from the outset of his employment, was described as such on the firm's notepaper and to other employees, and that the claimants were aware of this representation since the first claimant had been a client of the firm and would have seen its notepaper and his wife had been an employee of the firm while Prior worked there. However, there was no evidence that claimants had relied on the representation, and in fact they had advanced funds to the firm both before and after Prior's involvement in it. He therefore incurred no liability to them under s14.

Although true LLP membership generally has no significance to third parties, because LLP membership per se does not give rise to personal liability, ${ }^{87}$ there are exceptions to this. ${ }^{88}$ In addition, a shadow LLP member, that is to say a person who is not formally a member but 'in accordance with whose directions or instructions the members of the [LLP] are accustomed to act', other than a person who advises in a professional capacity, is liable to similar statutory sanctions relating to insolvency and disqualification orders to a true member. ${ }^{89}$ It may also be that the concept of a de facto LLP member will be recognised in the same way as that of a de facto director, ${ }^{90}$ the latter being a person who undertakes functions in relation to a company which could only properly discharged by a director, ${ }^{91}$ with the consequence that he is liable to similar insolvency sanctions and disqualification orders. However, as the role of an LLP member is materially different to that of a director, being much broader and having fewer statutory duties, the application of the de facto member concept is uncertain. ${ }^{92}$

\section{$6 \quad$ The challenges of determining status}

Given the significance of status and the prohibition on dual employee and partner/LLP member status (and possibly on worker and partner status), the determination of status is crucial. Unfortunately, it is not without its difficulties, for reasons that will now be analysed.

\footnotetext{
${ }^{84}$ Note also the Civil Liability (Contribution) Act 1978, s 3.

${ }^{85}$ Partnership Act, s 14.

86 (n12).

87 LLP Act, s 1(2).

88 See, for example, the LLP Act, s 6(4) and the Insolvency Act 1986, ss 213-214.

89 LLP Regulations 2001, Reg 2 and the Company Directors Disqualification Act 1986, s 22(5) as applied by the LLP Regulations 2001, Reg 4(2). See further Elspeth Berry and Rebecca Parry, Law of Insolvent Partnerships and LLPs (Wildy, Simmonds and Hill 2015) para 1.4.9.

90 John Whittaker and John Machell, The Law of Limited Liability Partnerships ( $3^{\text {rd }}$ edn, Bloomsbury Professional 2009) paras 8.41-8.42.

${ }_{91}$ Re Hydrodam (Corby) Ltd [1994] BCC 161 (Ch), 162 (Millet J).

${ }^{2}$ See further Berry and Parry (n89) para 1.4.10.
} 


\section{a) Partners/members}

The courts have emphasised on a number of occasions that what is crucial to true partner status (and, as discussed below, employment status) is

'the substance of the relationship between the parties....the question whether or not there is a partnership depends on what the true relationship is, and not on any mere label attached to that relationship' ${ }^{93}$ The same is true of LLP member status, registration as a member being merely a label and not conclusive of true member status. The LLP Act imposes substantive requirements similar to those of the Partnership Act for members to carry on a business together with a view of profit, ${ }^{94}$ and while it provides that the certificate of incorporation is conclusive proof that the LLP is incorporated ${ }^{95}$ it makes no equivalent provision for registration as a member to be conclusive. Indeed, $s 4(2)$ provides that admission as a member is effected by agreement with the other members rather than by registration, ${ }^{96}$ and although membership changes must be registered ${ }^{97}$ there is no provision for an unregistered change to be ineffective per se. ${ }^{98}$ The courts have certainly not regarded registration as conclusive; in Ondra ${ }^{99}$ the court held that Reinhard was a member despite the fact that he was not registered, while in Tiffin ${ }^{100}$ the Court of Appeal's reasons for holding Tiffin to be a member did not include that the fact that he was registered as such. ${ }^{101}$

The courts have also been alert to the risk of deliberate mislabelling of the relationship in order to avoid legal obligations that would otherwise arise, ${ }^{102}$ as has the legislature in relation to tax (discussed above). In Polegoshko and others $v$ Ibragimov and others ${ }^{103}$ the court ordered rectification of the register of LLP members on the grounds that it did not reflect the reality of the ownership of the LLP. Instead, the substantive factors determining whether a person is a true partner or LLP member include remuneration and whether it is fixed or dependent on profits, contribution to the firm's capital, involvement in management and decisionmaking, and appearances and description of status.

However, the position is sometimes obscured by the fact that a person may be held out as a partner to the outside world or registered as an LLP member, or treated as such by his co-partners/members for the purposes of internal rights and duties or profit shares, without necessarily being regarded as such by the law. This is because it is common in firms for there to be more than one type of partner or member, ${ }^{104}$ only some of who are true partner/members. Typically, there are equity partners/members who take part in management, contribute capital, and share profits; and other categories, including salaried and fixed share partners/members, which provide an intermediate status between equity partners/members and employees in terms of responsibility and remuneration. The EAT in Tiffin identified a salaried partner as one remunerated by a fixed or variable salary but held out to the world as a partner even though he does not enjoy all the rights of a partner, and noted that such a person can be a true

\footnotetext{
${ }^{93}$ Stekel v Ellice [1973] 1 WLR 191 (Ch) 199 (Megarry J).

${ }^{94}$ LLP Act, s 2(1) and Partnership Act, s 1(1).

95 LLP Act, s 3(2).

${ }_{96}$ LLP Act, s 4 and LLP Regulations 2001, Reg 7(5).

97 LLP Act, s 9.

98 LLP Act, s 6(3).

${ }^{99}$ (main judgment) (n18).

100 (n17).

101 The judgments in Clyde (n6) and Kovats (n29) make no reference to whether the respective claimants were registered as members.

102 Firthglow Ltd (trading as Protectacoat) v Szilagyi [2009] EWCA Civ 98, [2009] ICR 835.

103 [2015] EWHC 1669 (Ch), [2015] All ER (D) 273 (Jun).

104 See further James Davies, Clive Greenwood and Fergus Payne, Employment, Partnership and

Discrimination Law for Professional Partnerships (Legalease 2005) 7-16.
} 
partner (as in Stekel $v$ Ellice) or an employee (as in Briggs $v$ Oates ${ }^{105}$ ); ${ }^{106}$ as the court pointed out in Stekel,

'The term "salaried partner" is not a term of art and to some extent it may be said to be a contradiction in terms'. ${ }^{107}$

The EAT in Tiffin explained a fixed share partner as one who is principally remunerated by a fixed share of profits but is typically also entitled to a small share of residual profits and to participate in decisionmaking, and obliged to contribute a small sum of capital. ${ }^{108}$ Again, such a person could be a true partner/LLP member (as was Tiffin) or an employee. ${ }^{109}$ Section 2(3)(b) of the Partnership Act provides that the remuneration of an employee by a share of the partnership profits does not of itself make him a partner, and the courts have held that the absence of a right to share in profits does not prevent a person from being a partner. ${ }^{110}$

In Tiffin, in which an 'associate' (an employee) was promoted to a 'fixed share partner' in a partnership which then converted to an LLP, the Court of Appeal held that the provisions of the LLP agreement made it obvious that the relationship between the full equity members and the fixed share members (all of whom were defined by the agreement as 'equity partners') was one of true LLP membership; all had to contribute capital, all had a prospect of a share of profits, including a share of any surplus assets on winding up, and all had a say in management. ${ }^{111}$ The Court of Appeal contrasted this with the position under the agreement of salaried members, who had none of these rights, and ruled that the fact that the rights of the fixed share members might be much less than those of the equity members did not affect this conclusion. In Ondra, in which the LLP and Reinhard had entered into a contract which described the relationship as one of employment, the court held that Reinhard's entitlement to play a part in management and to share in the profits, including any surplus assets on winding up, led 'inevitably' to the conclusion that he was an LLP member rather than an employee. ${ }^{112}$ In Williamson and Soden Solicitors $v$ Briars ${ }^{113}$ the EAT held that the principal circumstance indicating partner rather than employee status was control in the sense of lawful authority to command. In Kovats ${ }^{114}$ it concluded that Kovats was a true member and not an employee because his role was consistent with the members' agreement and with the general duties of LLP members, he managed the business and his work was crucial to its success, he had considerable autonomy, he signed important documentation as a member which bound the LLP, he had some entitlement to a share of profits and to the proceeds on a winding up or sale, his drawings were paid gross and he accounted for income tax himself and paid self-employed national insurance contributions and, although he had made no direct capital contribution, he had accepted a significant reduction in salary when he joined the LLP.

\section{b) Employees}

\footnotetext{
105 (n64).

106 Tiffin v Lester Alldridge LLP UKEAT/0255/109/DM [2011] IRLR [7] (Silber J).

107 (n93) 198 (Megarry J); see further Lindley \& Banks on Partnership (n9) paras 5-54-5-56 and Mark

Butler and David Milman, 'Business participants and employment status: a review of the current position' (2012) 33(6) Comp Law 165.

108 (n106) [8] (Silber J).

${ }^{109}$ Cf Prassl, 'Members, partners, employees, workers? Partnership law and employment status revisited' (n33) 500 suggesting that fixed share status per se may be sufficient to denote employment status.

${ }_{110}$ Stekel (n93), M Young Legal Associates Ltd v Zahid (a firm) and others [2006] EWCA Civ 613, [2006] 1 WLR 2562 and Hodson v Hodson [2009] EWCA Civ 1025, [2010] PNLR 8.

111 (n17).

112 (main judgment) (n18) [45] (Warren J).

113 [2011] UKEAT 0611/10/2005, [2011] All ER (D) 101 (Aug).

114 (n29) [30] (Langstaff HJ).
} 
The key statutes which confer rights on employees, the Employment Rights Act $1996^{115}$ and the Trade Unions and Labour Relations (Consolidation) Act 1992,116 define an employee as an individual who has entered into or works under a contract of employment, and determining whether a particular individual is such a person has been a perennial problem for the courts. ${ }^{117}$ As with partner or LLP member status, the label which the parties attach to the relationship is not decisive of employee - or indeed worker - status: ${ }^{118}$ the courts have emphasised that it is necessary to consider all the factors and look at the overall picture. ${ }^{119}$ The purpose for which the determination of status is made may also affect that determination, as the courts have asserted a public policy interest in ensuing that statutory protection, including health and safety, ${ }^{120}$ is not avoided merely by reclassifying the claimant's status. ${ }^{121}$ In Autoclenz Ltd $v$ Belcher and others ${ }^{122}$ the Supreme Court described the key factors (many of which may be contrasted with those indicating partner/LLP member status) as follows:

(i) The employee agrees that, in consideration of a wage or other remuneration, he will provide his own work and skill in the performance of some service for his master ${ }^{123}$ (in contrast to a partner/LLP member typically sharing profits, albeit that this is not essential).

(ii) The employee agrees that in the performance of that service he will be subordinated to the other's control in a sufficient degree to make that other master ${ }^{124}$ (in contrast to the autonomy of a partner/LLP member ${ }^{125}$ ).

(iii) The other provisions of the contract are consistent with its being a contract of service (as opposed to, for example, a partnership or LLP agreement). ${ }^{126}$

(iv) There must be an irreducible minimum of obligation on each side, in other words the mutual obligations to provide and be available for work. ${ }^{127}$

(v) If a genuine right of substitution exists, ${ }^{128}$ this negates an obligation to perform work personally and is usually inconsistent with employee status. ${ }^{129}$ Indeed, personal service is a hallmark of both employment ${ }^{130}$ and partnership/LLP membership, in contrast

\footnotetext{
115 Section 230(1).

116 Section 295.

117 See further Freedland (n65) 14ff, Simon Deakin, The Law of the Labour Market: Industrialisation, Employment and Legal Evolution (2004 OUP) 303-313 and Guy Davidov, 'The Reports of My Death are Greatly Exaggerated: 'Employee' as a Viable (Though Over-used) Legal Concept' in Guy Davidov and Brian Langille (eds), Boundaries and Frontiers of Labour Law (2006 Hart).

118 Young \& Woods $v$ West [1980] IRLR 201 (CA).

119 Market Investigations Ltd $v$ Minister of Social Security [1969] 2 QB 173 (QB) approved and applied by the Privy Council in Lee Ting Sang v Chung Chi-Keung [1990] 2 AC 374 (PC). See also Castle Construction (Chesterfield) Ltd v HMRC [2008] UKSPC SPC00723, [2009] STC (SCD) 97 [68] (Howard M Nowlan Special Commissioner).

${ }^{120}$ Lane $v$ The Shire Roofing Company (Oxford) Ltd [1995] PIQR P417, 421 (Henry L]).

${ }^{121}$ Ferguson $v$ John Dawson and Partners (Contractors) Limited [1976] 1 WLR 1213 (CA).

122 [2011] UKSC 41, [2011] ICR 1157 [18-19] (Lord Clarke).

123 Ready Mixed Concrete (South East) Ltd v Minister of Pensions and National Insurance [1968] 2 QB 497 (QB) 515.

${ }^{124}$ Ready Mixed Concrete (n123).

${ }^{125}$ Although partners/LLP members do have some control over each other's work, and indeed over each other's property in the form of capital. See also Ronald H Coase, The Nature of the Firm (1937) 4(16) Economica 386, $403 \mathrm{n} 3$ and 404.

${ }^{126}$ Ready Mixed Concrete (n123).

127 Nethermere (St Neots) Ltd v Gardiner [1984] ICR 612 (CA) 623 (Stephenson LJ) and Carmichael v National Power plc [1999] ICR 1226 (HL).

${ }^{128} \mathrm{Cf}$ the mere existence of a substitution clause which does not reflect the real relationship

(Consistent Group Ltd v Kalwak Limited [2008] EWCA Civ 430 [2008] IRLR 505 [57] (Elias J), cited in Firthglow (n102) [54] (Smith L).

${ }^{129}$ Express \& Echo Publications Ltd v Tanton [1999] ICR 693 (CA) 699 (Peter Gibson L).

130 Stack v Ajar-Tec Ltd [2015] EWCA Civ 46, [2015] IRLR 474.
} 
to an independent contractor who can choose who he engages to perform the work contracted for. ${ }^{131}$

In addition, and of particular relevance in the partner/LLP member context, the courts will consider whether the individual is carrying on business on his own account with the associated financial risks - as do partners and LLP members, who usually have a direct interest in the profits of the firm, ${ }^{132}$ and in particular partners, who have unlimited personal liability ${ }^{133}$ - or merely doing so for another. ${ }^{134}$ Although a director who is also a controlling shareholder, and thus in reality working on his own account, has been held still to be capable of being an employee, ${ }^{135}$ the judgment in $C l y d e^{136}$ indicates that this approach will not be taken to LLP members because s4(4) has aligned them with partners rather than directors, and the lack of a separate person to work for has prevented this approach being taken to partners. Other factors which have been held to be relevant include whether it is a permanent engagement unrelated to a specific duration or task, ${ }^{137}$ the provision of the necessary facilities and equipment by the business, ${ }^{138}$ the integration of the person into the business, ${ }^{139}$ and the intentions of the parties. ${ }^{140}$ Functionally, it is therefore possible for a partnership or LLP to behave as an employer, ${ }^{141}$ but the pertinent question is whether a particular person is its employee or a true partner/member. Lady Hale in Clyde stated that there was no 'magic test', in particular a relationship of subordination, to determine whether a person was an employee or a worker, and that it depended on the wording of the statute. ${ }^{142}$ This apparently overrules the judgment of the Supreme Court only three years earlier in Jivraj $v$ Hashwani, in which it held that subordination was an essential element in the employment relationship, ${ }^{143}$ and allows the employment relationship, with its associated protections, to be construed more widely. ${ }^{144}$

In the lights of these criteria, or those for partnership, the EAT in Williamson ${ }^{145}$ concluded that an employee who was promoted to a salaried partner was still an employee. It noted that he took no significant risk of loss, the fact that he shared in profits could be persuasive towards partner status but was not determinative, he was subject to the control of the firm, the governance of which was within the hands of the equity partners on essential matters, and the parties behaved as if he was still an employee. Had a change from employment to partner status been intended by the parties, it was to be expected that the paperwork would have more clearly reflected that change given the significant obligations on partners imposed by the authority and liability provisions of the

\footnotetext{
131 The courts have recognised a very limited exception where employees' contracts permitted them to provide a substitute only when they were unable to work and only from a list of substitutes provided by the employer, and the employer paid the substitute directly and indeed sometimes arranged the substitution (Macfarlane and ington $v$ Glasgow City Council [2000] UKEAT 1277/99/1075, [2001] IRLR 7).

132 Partnership Act 1890, s 24(1) and the LLP Regulations 2001, Reg 7(1).

133 Partnership Act, s 9 and the Civil Liability (Contribution) Act 1978, s 3.

${ }_{134}$ Market Investigations Ltd (n119) 184-185 (Cooke J).

135 Lee $v$ Lee's Air Farming Ltd [1961] AC 12 and Secretary of State for Business, Enterprise and Regulatory Reform v Neufeld [2009] EWCA Civ 280, [2009] 3 All ER 790.

136 (n6).

137 Davies v Braithwaite [1931] 2 KB 628 (KB).

138 Market Investigations Ltd (n119).

139 Market Investigations Ltd (n119).

140 Express \& Echo Publications (n129).

141 Prassl, 'Members, partners, employees, workers? Partnership law and employment status revisited' (n33) 500.

142 Clyde (n6) [39].

143 [2011] UKSC 40, [2011] 1 WLR 1872 [27], [34], [39] (Lord Clarke).

144 Prassl, 'Members, partners, employees, workers? Partnership law and employment status revisited' (n33) 503.

145 (n113).
} 
Partnership Act. In contrast, in Train ${ }^{146}$ the EAT concluded that Train was not an employee but a partner, even though he and his four former partners had formed companies (in which they were all shareholders) to operate the business and he was paid through the PAYE system, had a fixed holiday entitlement, devoted the whole of his time to the business, was integrated into it and was held out as being an employee, because he had no written contract of service, his salary was liable to vary according to profits and there was limited control over his work and limited mutuality of obligation.

\section{c) Workers}

In recent years, statutory rights have often been given to the wider category of 'workers' rather than employees, which increases the range of individuals to whom the relevant statutory protections apply. The legislation generally defines a worker as an individual who works under a contract of employment, or under 'any other contract.... whereby the individual undertakes to do or perform personally any work or services for another party to the contract whose status is not by virtue of the contract that of a client or customer of any profession or business undertaking carried on by the individual', ${ }^{147}$ although the exact wording of the exclusion of client contracts varies ${ }^{148}$ and not all statutes contain this exclusion. ${ }^{149}$ The Transfer of Undertakings (Protection of Employment) Regulations $2006^{150}$ (TUPE Regulations) refer to an employee but define it in similar terms as 'an individual who works for another person whether under a contract of service or otherwise' excluding 'anyone who provides services under a contract for services'. As with employees, the label is not conclusive, and the purpose for which status is being determined may be influential, for example the protection of a whistleblower in Clyde.

The Supreme Court in Clyde $e^{151}$ agreed with Maurice Kay LJ in Hospital Medical Group Ltd $v$ Westwood ${ }^{152}$ that neither the integration of the worker in the business (as opposed to his being able to market his services to the world) nor the dominant purpose of the contract being the provisions of personal services (as opposed to them being an ancillary feature) were determinative, but also held (contrary to its earlier judgment in Jivraj $v$ Hashwani ${ }^{153}$ ) that it was not essential for there be an element of subordination; it was more important to focus on applying the words of the statute in question to the facts of the case at issue, and no single test of worker status was determinative. ${ }^{154}$ This apparent minimising of the importance of subordination reflects the fact that the traditional view of individuals obeying orders in determining the organisation of their work is not well adapted to professional service firms, ${ }^{155}$ in which individuals typically enjoy a considerable degree of autonomy and independence and owe duties to clients. ${ }^{156}$ Subordination also potentially conflicts with the requirement of mutuality of obligation, and indeed the latter appears to have been accorded more weight in

\footnotetext{
146 (n5).

147 Employment Rights Act 1996, s 230(3)(b); see also the Trade Union and Labour Relations

(Consolidation) Act 1992, s 296 and the Pensions Act 2008, s 88.

${ }_{148}$ For example, the Employment Relations Act 1996, s 230(3) defines a worker similarly except that it excludes a contract with a person who is a client or customer of any profession or business carried on by the individual, rather than a contract with a professional client.

${ }^{149}$ For example, the Equality Act 2010, s 83(2).

150 SI 2006/246, Reg 2(1).

$151(\mathrm{n} 6)$.

152 [2012] EWCA Civ 1005, [2013] ICR 415.

153 (n143).

154 (n6) [39] (Lady Hale).

155 See further Arturo Bronstein, International and Comparative Labour Law: Current Challenges (Palgrave Macmillan and the International Labour Office 2009), 45-49.

156 Hugh P Gunz and Sally P Gunz, 'Professional Ethics in Formal Organizations' in Royston Greenwood and Roy Suddaby (eds), Professional Service Firms (Emerald Group 2006).
} 
relation to casual workers, ${ }^{157}$ which exemplifies the lack of coherence in this area. However, subordination should not be discounted entirely as it is is still relevant when considering whether the individual is working for the firm or on their own account, and thus whether the centre of gravity of the relationship tends towards the firm's business or the individual's own business. ${ }^{158}$ Although Bates van Winkelhof was a junior equity LLP member, received a share of profits and worked principally in an associated firm overseas, the Supreme Court concluded that she was a worker for the purposes of s230(3)(b) of the Employment Rights Act 1996 (and could thus benefit from the protection given to whistleblowers) because she could not market her services to anyone other than the LLP and was an integral part of the business, and the LLP was in no sense her client or customer.

Whether a true LLP member can be a worker for the purposes of other statutes will of course depend on the definition of a worker used in the legislation and the particular facts of the case. ${ }^{159}$ For example, the exclusion from the definition in the TUPE Regulations of a person who provides services under a contract for services covers, as Glidewell J noted in Cowell, 'precisely the position of a normal equity partner'160 and thus of an equity LLP member. Furthermore, as discussed above, the government has already limited the application of worker pension protection to LLP members.

Whether true partners can also, in principle, be workers, has not yet been established. Public Concern at Work recommended that both partners and LLP members be explicitly included in the definition of 'worker' for the purposes of whistleblowing protection ${ }^{161}$ but the government concluded that the judgment in Clyde made further legislative change unnecessary in relation to LLP members ${ }^{162}$ and, unfortunately, overlooked the remaining question of the status of partners: its guidance on whistleblowing now states that an LLP member is protected but makes no reference to partners. ${ }^{163}$

In Clyde, Lady Hale noted that the question of whether partners could be workers was 'a very different question from whether they can be employees' ${ }^{\prime 64}$ and Lord Carnwath emphasised that the ruling did 'not necessarily have any direct relevance to the resolution of equivalent issues in relation to other forms of partnership'. ${ }^{165}$ This has been taken by some to indicate that the distinction between employees and workers is 'a much more stark one than hitherto assumed', ${ }^{166}$ but it is more likely that the Supreme Court was merely emphasising

157 O'Kelly and others $v$ Trusthouse Forte plc [1984] QB 90 (CA), 106 (Ackner L]) citing the judgment of the Industrial Tribunal, and Carmichael (n125). However, O'Kelly was decided before the full development of the requirement of mutuality of obligations, and its main focus was on the issue of the appeal process in tribunal cases.

${ }^{158}$ Bob Hepple, Restructuring Employment Rights (1986) 15 ILJ 69, 75.

159 Clive Greenwood and Christopher Hitchins, 'Pensions: enrolment and partnerships' (2014) 111(24) LS Gaz 20.

160 (n4) 394. This case concerned the identical definition in the predecessor to that legislation, the Transfer of Undertakings (Protection of Employment) Regulations 1981 (SI 1981/1794).

${ }^{161}$ The Whistleblowing Commission, Report on the effectiveness of existing arrangements for workplace whistleblowing in the UK (November 2013)

<www.pcaw.org.uk/files/WBC\%20Report\%20Final.pdf> accessed 25 May 2016.

162 BIS, Whistleblowing Framework Call for Evidence: Government Response (June 2014) 17

$<$ www.gov.uk/government/uploads/system/uploads/attachment_data/file/323399/bis-14-914whistleblowing-framework-call-for-evidence-government-response.pdf> accessed 25 May 2016. 163 Whistleblowing for employees (updated 2 July 2015) <www.gov.uk/whistleblowing > accessed 25 May 2016.

164 (n6) [26].

165 (n6) [55].

166 Prassl, 'Members, partners, employees, workers? Partnership law and employment status revisited' (n33) 502. 
that its judgment was limited to LLP members, and that existing caselaw on partners was limited to their employment status.

The key element in worker status and the rationale for the associated regulatory protection is the individual's dependency on the relationship, which arises from the exclusivity of the engagement - in the case of partners as with LLP members - as opposed to him being able to spread his risks among a number of different relationships; ${ }^{167}$ whether the engagement gravitates towards the firm's business or that of the individual. ${ }^{168}$ As the EAT explained in Byrne Bros (Formwork) Ltd $v$ Baird and Others: 169

'The reason why employees are thought to need such protection is that they are in a subordinate and dependent position vis-à-vis their employers: the purpose of the Regulations is to extend protection to workers who are, substantively and economically, in the same position. Thus the essence of the intended distinction must be between, on the one hand, workers whose degree of dependence is essentially the same as that of employees and, on the other, contractors who have a sufficiently arm'slength and independent position to be treated as being able to look after themselves in the relevant respects.'

However, similar policy arguments could be made in respect of employee shareholders (employees granted shares in their employer which have a minimum value of $£ 2000$ ), yet they are automatically deprived of certain employment rights that they would otherwise have. ${ }^{170}$ Moreover, this passage was cited by the Court of Appeal in Redrow Homes (Yorkshire) Ltd $v$ Wright Roberts and others $v$ Redrow Homes (North West) Ltd ${ }^{171}$ with the significant caveat, reflected in the Supreme Court's ruling in Clyde, that the focus must remain on the statutory definition of the term 'worker' and the obligations of the parties under the contract. It may therefore be that a partner cannot be a worker because the definition requires the individual to work under a contract for 'another party' and while an LLP is another party; because it is a separate legal person, a partnership is not, because it includes the (true) partner himself. ${ }^{172}$

\section{$7 \quad$ Conclusion}

The answer currently given by the courts to the question of when a partner or LLP member is not actually a partner or member, is that a person who purports to be a partner or member cannot be a true partner/member if he is also an employee. This is despite the fact that a person who is a sole company director and controlling shareholder can simultaneously be an employee and that, absent s4(4) of the LLP Act which aligns LLP members with partners instead, a true LLP member might be though to be in an analogous position for the purposes of employment law, given that both companies and LLPs have separate legal personality. In contrast, those who are merely held out as partners or registered as LLP members (but are not true partners or members) can seemingly possess this more limited status simultaneously with employee status. An LLP member can be both a true member and a worker, although it is not yet clear whether a true partner can be a worker.

What the law requires here is greater clarity. First, the legislation should state clearly that a true LLP member or partner cannot simultaneously be an employee, but that nothing in the legislation prevents such a person from being a worker.

\footnotetext{
167 Guy Davidov, 'Who is a worker?' (2005) Ind L 57, 62-63 and 67.

168 Hepple (n157).

169 [2002] ICR 667 [17] (Mr Recorder Underhill QC).

170 Employment Relations Act 1995, s 205A; see further Jeremias Prassl, 'Employee shareholder

"status": dismantling the contract of employment' (2013) 42(3) Ind LJ 307.

171 [2004] EWCA Civ 469, [2004] ICR 1126 [17] (Pill L).

172 Lindley \& Banks on Partnership (n10) para 5-57 and Cowell (n4) 394 (Glidewell LJ).
} 
This would reflect the jurisprudence on the employment status of partners and (arguably) LLP members, and the worker status of LLP members. While the worker status of partners has not yet been established, a legislative statement to this effect would overcome the difficulties for the courts of taking such an approach, and it is justified by the arguments set out above for the application of worker protection to those in a dependent relationship. Second, the legislation should explain the distinction between true partners or members, and other types of partner or member. The jurisprudence gives some guidance as to the factors which determine true partner or member status (for example, management, capital contribution and profit sharing), but neither the partnership nor the LLP legislation refers to this, or to its interaction with relevant provisions of tax law. The legislation should reflect current commercial practice by setting out the indicators of true partner or member status established by the courts and, in the case of the LLP legislation, could also utilise the criteria adopted in the tax legislation on the disguised employment of LLP members. ${ }^{173}$ Third, the legislation should clarify the significance of this distinction. The LLP Act should explain, as does s14 of the Partnership Act in relation to those held out as partners, that those who are merely registered as members may incur liability to third parties as true members (including in the circumstances set out in s6(4) of the LLP Act and other exceptions to limited liability as established in the company context). Both the partnership and the LLP legislation should also confirm that such persons will not be treated as true partners or members for other purposes such as tax or discrimination legislation, and should state that nothing in the partnership or LLP legislation prevents them simultaneously being employees or workers under employee or worker protection legislation.

The terms 'employee' and 'worker' are also ripe for clarification; the statement that 'the judicial concepts approach anarchy'174 made over 30 years remains with the possible addition of the legislative concepts - true today. The law discussed in this article in relation to partners and LLP members reflects the wider context in which an increasing number of labour relationships fall outside the traditional concept of an employment contract and thus potentially outside the scope of the statutory protections offered to employees. ${ }^{175}$ The courts have been prepared to take a flexible approach in order to prevent this, ${ }^{176}$ albeit at the expense of coherence in the law, but it needs to be recognised in both the partnership/LLP legislation and the employment protection legislation that the relationships between true partners, or between true LLP members and their LLP, are fundamentally different to, and therefore quite properly not regarded as, employment relationships. In contrast, the legislature's increasing use of the term 'worker' has brought true LLP members within the scope of at least some statutory worker protection, but carve-outs have already been made in relation to pensions, and in the absence of judicial confirmation of partners' worker status or lack thereof, legislative clarification is needed; LLPs are already examining the application of worker rights to their members, and partnerships need to know whether they should be doing the same. ${ }^{177}$

\footnotetext{
$173(n 36)$.

174 Jon Clark and Lord Wedderburn, 'Modern Labour Law: Problems, Functions and Policies', in Labour Law and Industrial Relations: Building on Kahn-Freund (Lord Wedderburn, Roy Lewis and Jon Clark (eds) (1983 Clarendon).

175 See further Simon Deakin, 'The Comparative Evolution of the Employment Relationship' in Davidov and Langille (eds) (n117).

176 Ferguson (n121).

177 See, for example, Clare Murray, 'Members as workers' (2014) 16(10) MP 72 and Sarah Ozanne, 'New rights for partners' (2014) Jul/Aug Emp LJ 15, 17.
} 